\title{
EVALUATION OF DECORATIVE VALUE OF SELECTED TAXA OF THE GENUS Digitalis
}

\author{
Dorota Janicka, Krzysztof Wraga, Agnieszka Zawadzińska
}

\author{
West Pomeranian University of Technology in Szczecin, Department of Ornamental Plants, \\ Papieża Pawła VI 3A, 71-459 Szczecin, Poland \\ e-mail: kwraga@zut.edu.pl
}

Received: 09.03.2011

\section{Abstract}

In the years 2008-2010, evaluation of decorative value of Digitalis grandiflora Mill., D. laevigata Waldst. et Kit., D. lanata Ehrh., D. lutea L., D. × mertonensis 'Summer King', D. purpurea L. 'Apricot', 'Foxy','Pam's Choice' and D. thapsi L. 'Spanish Peaks ${ }^{\circledR \text { ' }}$ was carried out. Plants were evaluated at the vegetative and generative stage.

Foxglove seedlings were characterized by high quality, proportional rosettes, healthy appearance, and they were without pests or diseases. Of all the cultivars tested, D. purpurea and D. $\times$ mertonensis 'Summer King' flowered earliest. Digitalis laevigata and D. lanata reached a high decorative value latest. Digitalis lutea, D. lanata and D. laevigata flowered most abundantly. Digitalis purpurea 'Apricot' had the longest inflorescences with large flowers. Digitalis $\times$ mertonensis 'Summer King' had short inflorescences, but with very densely set flowers. All the taxa evaluated were characterized by high decorative quality. They can be grown in fields in the climatic conditions of northwestern Poland. Digitalis $\times$ mertonensis 'Summer King', D. purpurea 'Apricot' and 'Pam's Choice' were of the highest decorative value.

Key words: Digitalis, foxglove, seedlings, flowering, decorative value.

\section{INTRODUCTION}

Many new species and cultivars of ornamental plants used in green areas appear in the world horticultural market each year. Many of them are characterized by high decorative value and small requirements. Foxgloves cultivated as biennial plants or as short-lived perennial plants belong to this plant group. There are about 20 species of the genus Digitalis in the nature, but the number of taxa offered by seed companies is much greater, for example, a well-known German seed company offers as many as 27 taxa, including 14 cultivars of D. purpurea. A limited number of species and cultivars of that genus are cultivated in Poland. Common foxglove (Digitalis purpurea L.) and its selected cultivars, 'Excelsior' and 'Gloxiniaeflora' especially, are cultivated most often (Ś w i d z i ń s k a, 2000; M a r c in k ow s k i, 2002).

Although foxgloves are characterized by small requirements and simple cultivation, they are seldom used in green areas in Poland (parks, lawns, etc.). They are more often cultivated as bedding plants in allotments and adjacent gardens ( $\mathrm{H} \mathrm{e} \mathrm{ll}$ w i g, 1975; B e r $\mathrm{n}$ a c i a k et al. 2007). Foxgloves are also seldom cultivated for cut flowers (Nowak and Rudnicki, 1990; Armitage and Laushman, 2008). It is worth to know the new taxa and those which had been cultivated in Polish gardens in the past, but were forgotten (Olge lbra nd, 1865).

The aim of the present research was the evaluation of decorative value of some taxa of the genus Digitalis, including unknown or rare taxa cultivated in Poland.

\section{MATERIALS AND METHODS}

The experiment was carried out in the growing seasons 2008/2009 and 2009/2010 in the experimental field plots of the Department of Ornamental Plants of West Pomeranian University of Technology in Szczecin.

Nine taxa of the genus Digitalis were used as plant material: D. grandiflora Mill. (syn. D. ambiqua Murray) - big-flowered foxglove, large-flowered foxglove (Fig. 1), D. laevigata Waldst. et Kit. - Grecian foxglove (Fig. 2), D. lanata Ehrh. - woolly foxglove (Fig. 3), D. lutea L. - yellow foxglove (Fig. 4), D. $\times$ mertonensis Buxton et C.D.Darl. 'Summer King' 
- strawberry foxglove, Merton's foxglove (Fig. 5), D. purpurea L. 'Apricot' (syn. 'Sutton's Apricot') common foxglove (Fig. 6), D. purpurea 'Foxy' (syn. 'Foxy Mix') - Fig. 7, D. purpurea 'Pam's Choice' (syn. 'Elsie Kelsey') - Fig. 8, and D. thapsi L. 'Spanish Peaks ${ }^{\circledR}$ ' (Fig. 9) - fingerhut foxglove (Armitage and Laushman, 2008; Erhardt et al. 2008; https://www. jelitto.com).

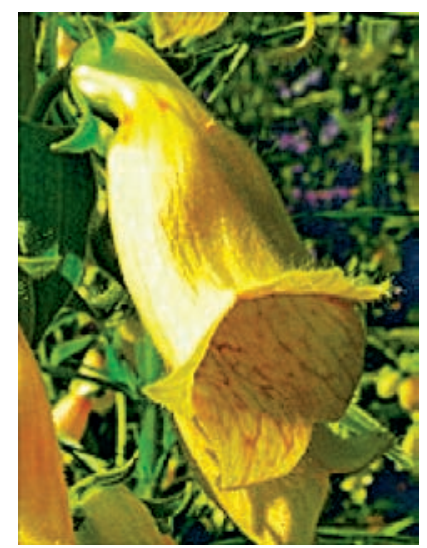

Fig. 1. D. grandiflora

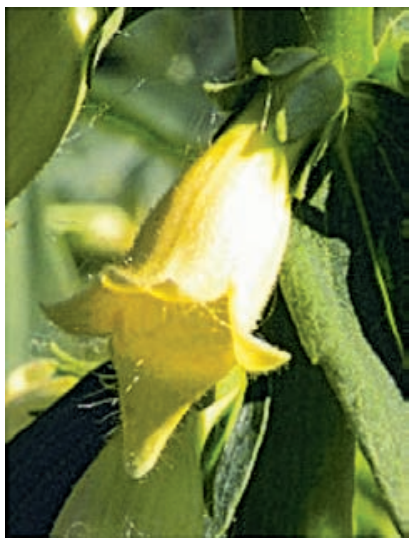

Fig. 4. D. lutea

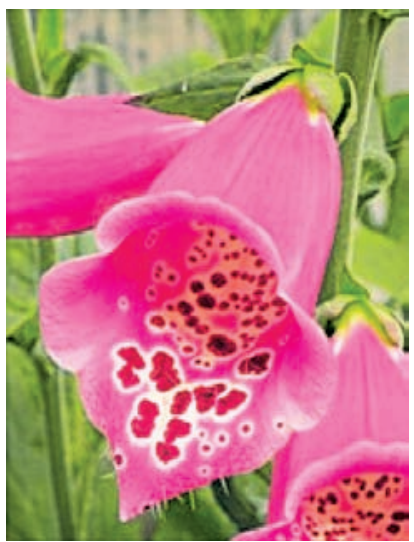

Fig. 7. D. purpurea 'Foxy'

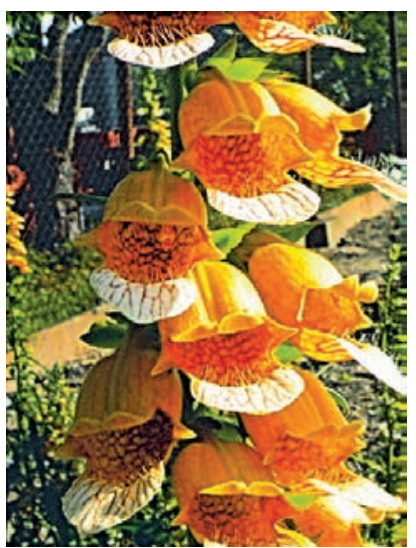

Fig. 2. D. laevigata

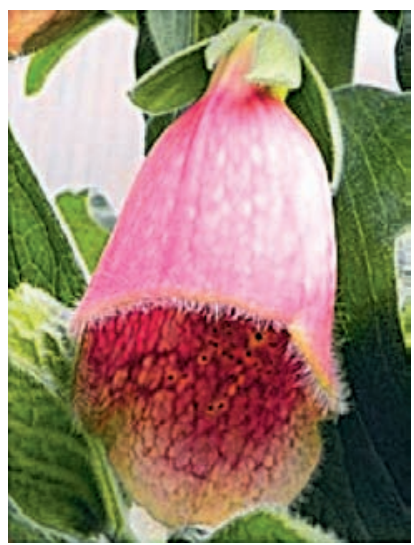

Fig. 5. D. $\times$ mertonensis

'Summer King'

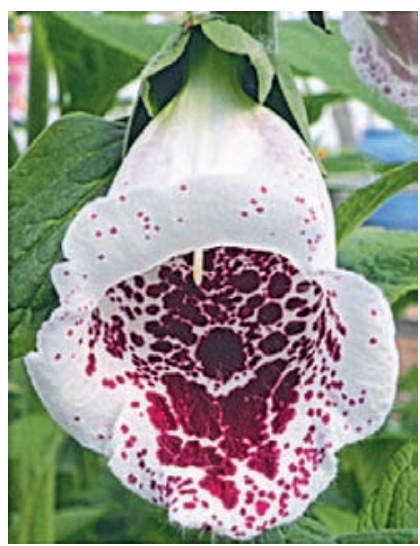

Fig. 8. D. purpurea

'Pam's Choise'

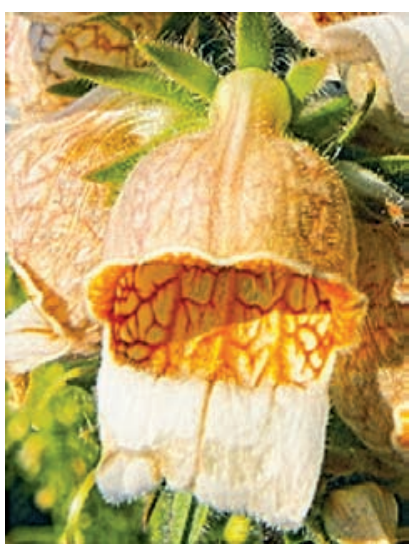

Fig. 3. D. lanata

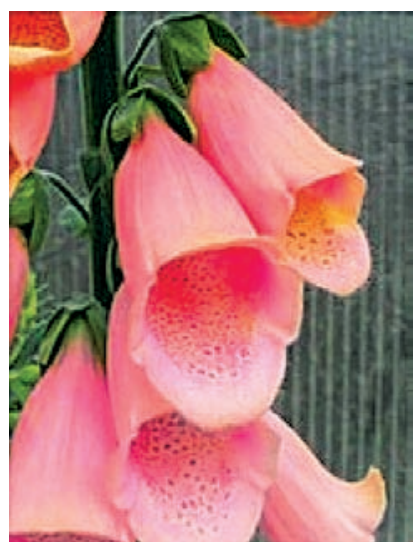

Fig. 6. D. purpurea

'Apricot'

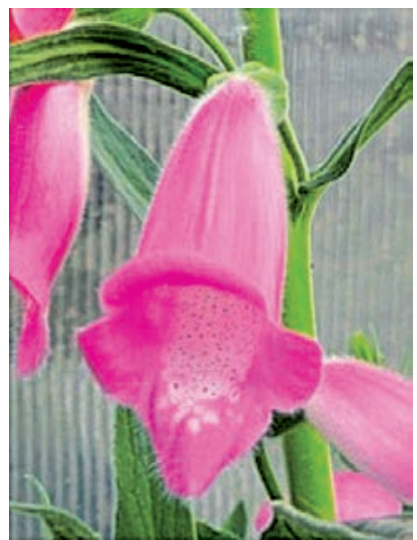

Fig. 9. D. thapsi

'Spanish Peaks ${ }^{\circledR}$
In the first and in the second growing season, plant material was obtained from seeds of the Jelitto company. Seeds were sown in the middle of May in a specialist growing medium from the Hollas company. 7 weeks after sowing, seedlings were transplanted to $12-\mathrm{cm}$ pots in the medium prepared on the basis 
of deacidified peat from the Hartmann company $(\mathrm{pH}$ 5.5-6.5), which was supplemented with Azofoska $(13.6+1.9+16.0)$ at a rate of $2.5 \mathrm{~g} \times \mathrm{dm}^{-3}$. Seedlings were cultivated in an unheated foil tunnel until the moment when they were planted in open ground. Basic cultivation measures were carried out - watering, weed removal, and double fertilization using Peters Professional Foliar Feed $(27+15+12)$ at a concentration of $0.2 \%$. In both years of the study - in the middle of August in the year 2008 and in the middle of August in the year 2009, seedlings were planted in open ground at a row spacing of $30 \times 30 \mathrm{~cm}$ and grew there until the end of the experiment $\left(1^{\text {st }}\right.$ decade of July 2009 and $1^{\text {st }}$ decade of July 2010). The plants were grown in a sunny position, in sandy clay soil with a $\mathrm{pH}$ of 7.07.5. No winter covering was used in order to protect them from below-zero temperature. Both experiments were established using a completely randomized design, in 3 replications, 5 plants per replication.

In the middle of March in 2009 and at the end of March in 2010, respectively, additional fertilization was carried out using Azofoska fertilizer at a rate of

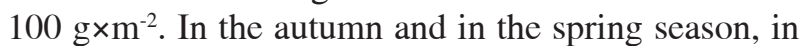
both years of the experiment elementary cultivation measures were carried out: weed removal, watering, and plant protection (according to the current recommended ornamental plant protection programme).

Before planting foxgloves, measurements of vegetative traits of plants were carried out on 15 randomly selected foxgloves. Leaves in the rosette were counted as well as length and width of leaf blades were measured. The leaf greenness index (SPAD), highly correlated with chlorophyll content, was also measured using a Chlorophyll Meter SPAD-502 (G r e g o r c z y k and $\mathrm{R}$ a c z y ń s k a, 1998). To measure the leaf greenness index, three properly formed leaves were selected from the middle part of the rosette. At the stage of at least one inflorescence on each plant, at the growth stage from P2 - anterior anthers dehisced, to P4 - all anthers dehisced (S te a d and M o o r e, 1977), at the stage of full decorative value, measurements of selected vegetative and generative traits were carried out from the end of May to the end of June in the 2008/2009 season and from the beginning of June to the beginning of July in the 2009/2010 season, depending on the evaluated taxon. Number of leaves in the rosette and the leaf greenness index were determined. Plant height from the stem base to the top of the highest inflorescence was measured. Length of the inflorescence was measured and flowers were counted on the highest inflorescence stem. Length from the calyx base to the edge of the corolla was measured on 9 randomly selected flowers. The results were verified statistically using the analysis of variance and the differences between means were verified using ANALWAR 4.3. software and
Tukey's test at the significance level $\alpha=0.05$. Statistically verified results of the measurements and observations regarding the growth stages of plants and evaluation of decorative value in both seasons of the study were taken into account during the investigations.

\section{RESULTS AND DISCUSSION}

Good quality of seedlings is one of the most important aims in large-scale production of seasonal ornamental plants. Success of cultivation depends on it to a large degree. Foxgloves are often sold by the producers in the stage of a several-leaf rosette. It is important, because customers buying ornamental plants are often influenced by the quality of seedlings ( $\mathrm{N} \mathrm{a} \mathrm{u}, 1993$ ).

In the present experiments, both in 2009 and in 2010 Digitalis purpurea 'Apricot' had significantly the most leaves (Table 1 ) in the rosette (20.0 and 27.3 leaves, respectively), whereas $D . \times$ mertonensis 'Summer King' (10.4 and 9.7 leaves, respectively) and D. lanata (11.1 and 10.5 leaves, respectively) were characterized by the smallest number of leaves in the rosette. Other taxa did not differ significantly in number of leaves in the rosette in each year of the experiment. In both years, D. purpurea 'Pam's Choice' had the longest and the widest leaf blades. Leaves of that cultivar reached the length of $30.0 \mathrm{~cm}$ and width of $13.0 \mathrm{~cm}$, on the average. Digitalis laevigata (leaf length of 8.6 and $16.8 \mathrm{~cm}$, respectively), D. grandiflo$\mathrm{ra}$ (leaf length of 10.0 and $14.1 \mathrm{~cm}$, respectively), and D. lanata (leaf length of 11.6 and $13.5 \mathrm{~cm}$, respectively) had the shortest leaves in 2009 as well as in 2010. These taxa were also characterized by the narrowest leaf blades: D. laevigata -2.1 and $2.8 \mathrm{~cm}, D$. grandiflora -3.5 and $4.4 \mathrm{~cm}, D$. lanata -2.5 and $2.8 \mathrm{~cm}$. $D$. lutea had equally narrow leaf blades (4.0 and $4.6 \mathrm{~cm})$. D. lanata was characterized by the greenest leaves; its leaf greenness index was especially high in the second year of the research (50.6 SPAD). In the first year of the experiment, leaves of D. laevigata and $D$. purpurea 'Apricot' had the lowest leaf greenness index. In the second year, the leaf greenness index of the other taxa of foxgloves was similar, except for D. lanata. 13 weeks after seed sowing (in the middle of August 2008 and 2009), all evaluated taxa of the genus Digitalis had several-leaf, bottle green, healthy rosettes. In 2009 the obtained seedlings had more slightly greener leaves with larger leaf blades than in 2008. Among the evaluated taxa, three cultivars of $D$. purpurea ('Apricot', 'Foxy', and 'Pam's Choice') and D. × mertonensis 'Summer King' were of high quality with regard to the size of rosettes as well as the shape and colour of leaves. These traits affect plant attractiveness. 
Table 1.

Morphological traits of Digitalis sp. at the vegetative stage

\begin{tabular}{|c|c|c|c|}
\hline \multirow{2}{*}{ Trait } & \multirow{2}{*}{ Taxon } & \multicolumn{2}{|c|}{ Year } \\
\hline & & 2009 & 2010 \\
\hline \multirow{11}{*}{ Number of leaves } & D. grandiflora & 19.0 & 14.2 \\
\hline & D. laevigata & 11.1 & 10.5 \\
\hline & D. lanata & 16.3 & 20.2 \\
\hline & D. lutea & 16.9 & 20.0 \\
\hline & D. $\times$ mertonensis 'Summer King' & 10.4 & 9.7 \\
\hline & D. purpurea 'Apricot' & 20.0 & 27.3 \\
\hline & D. purpurea 'Foxy' & 15.6 & 16.2 \\
\hline & D. purpurea 'Pam's Choice' & 16.3 & 14.5 \\
\hline & D. thapsi 'Spanish Peaks ${ }^{\circledR ’}$ & 16.7 & 19.8 \\
\hline & $\underline{\text { Mean }}$ & 15.8 & 16.9 \\
\hline & $\underline{\mathrm{LSD}_{0.05}}$ & 6.79 & 6.58 \\
\hline \multirow{11}{*}{ Green index (SPAD) } & D. grandiflora & 37.1 & 34.5 \\
\hline & D. laevigata & 35.0 & 40.9 \\
\hline & D. lanata & 45.4 & 50.6 \\
\hline & D. lutea & 38.4 & 36.7 \\
\hline & D. $\times$ mertonensis 'Summer King' & 43.3 & 41.4 \\
\hline & D. purpurea 'Apricot' & 35.5 & 35.4 \\
\hline & D. purpurea 'Foxy' & 39.6 & 40.0 \\
\hline & D. purpurea 'Pam's Choice' & 39.9 & 39.1 \\
\hline & D. thapsi 'Spanish Peaks ${ }^{\circledR ’}$ & 39.5 & 42.3 \\
\hline & $\underline{\text { Mean }}$ & 39.3 & 40.1 \\
\hline & $\underline{\mathrm{LSD}_{0.05}}$ & 6.55 & 7.10 \\
\hline \multirow{11}{*}{ Length of lamina $(\mathrm{cm})$} & D. grandiflora & 10,0 & 14.1 \\
\hline & D. laevigata & 8.6 & 16.8 \\
\hline & D. lanata & 11.6 & 13.5 \\
\hline & D. lutea & 16.4 & 19.6 \\
\hline & D. $\times$ mertonensis 'Summer King' & 21.7 & 19.3 \\
\hline & D. purpurea 'Apricot' & 23.8 & 26.7 \\
\hline & D. purpurea 'Foxy' & 26.7 & 27.8 \\
\hline & D. purpurea 'Pam's Choice' & 29.3 & 29.7 \\
\hline & D. thapsi 'Spanish Peaks ${ }^{\circledR ’}$ & 20.7 & 21.3 \\
\hline & $\underline{\text { Mean }}$ & 18.8 & 21.0 \\
\hline & $\underline{\mathrm{LSD}} \underline{\underline{0.05}}$ & 3.5 & 3.25 \\
\hline \multirow{11}{*}{ Width of lamina $(\mathrm{cm})$} & D. grandiflora & 3.5 & 4.4 \\
\hline & D. laevigata & 2.1 & 4.0 \\
\hline & D. lanata & 2.5 & 2.9 \\
\hline & D. lutea & 4.0 & 4.6 \\
\hline & D. $\times$ mertonensis 'Summer King' & 12.0 & 10.2 \\
\hline & D. purpurea 'Apricot' & 10.1 & 11.1 \\
\hline & D. purpurea 'Foxy' & 9.5 & 10.2 \\
\hline & D. purpurea 'Pam's Choice' & 12.7 & 12.5 \\
\hline & D. thapsi 'Spanish Peaks ${ }^{\circledR ’}$ & 8.5 & 9.7 \\
\hline & $\underline{\text { Mean }}$ & 7.2 & 7.7 \\
\hline & $\underline{\mathrm{LSD}_{0.05}}$ & 1.73 & 2.34 \\
\hline
\end{tabular}


In both experimental seasons, all the plants grew and flowered properly after winter. No damage of leaf blades under the influence of below-zero temperature was found, either.

The taxa used in the experiment differed in time and length of flowering. D. purpurea 'Foxy' flowered most quickly - in the year of seeding (i.e. in the middle of September in 2008 and in 2009). According to Stead and Moore (1977) as well as M a c o b o y (2003) and Brickell (1999), this cultivar can be cultivated as an annual plant, because a part of plants flower in the first year of cultivation without winter vernalization. In our own research, plants flowering in the year of seed sowing were also obtained - in the year 2008 about $25 \%$ of plants of this cultivar flowered and in 2009 almost $35 \%$ of plants flowered. This flowering was not too abundant; the plants were usually characterized by one inflorescence stem with 20-30 flowers. The shortening of the vegetative stage and the faster onset of the generative stage of 'Foxy' cultivar was probably caused by DLI - daily light integral (http://www.hrt. msu.edu/perennialresearch/Perennial/Summary/Digitalis_Foxy.pdf). It is recommended to sow seeds of this cultivar earlier than in traditional cultivation, i.e. about 5 months before planned time of flowering, to obtain more flowering plants (B r e $\mathrm{n} \mathrm{z} \mathrm{e} \mathrm{1,} \mathrm{2001).} \mathrm{In} \mathrm{this} \mathrm{rese-}$ arch, a later date of seeding than the recommended one could have resulted in a smaller percentage of plants having inflorescence stems in the year of seeding.

In the second year of the study, between the end of May and beginning of June in the year 2009 and in the first decade of June in the year 2010, the cultivars of D. purpurea (Apricot, Foxy, Pam's Choice), and D. $\times$ mertonensis 'Summer King' were most quickly of the greatest decorative value. D. grandiflora, D. lutea, and D. thapsi 'Spanish Peaks ${ }^{\circledR}$ ' were at full flowering in the second decade of June in the years 2009 and 2010. D. laevigata and D. lanata bloomed latest, in the third decade of June in 2009 and between the end of June and beginning of July in 2010.

Cultivars of Digitalis purpurea, with inflorescence stems reaching a height of $80-150 \mathrm{~cm}$, are usually used in green areas. These are biennial plants, sometimes short-lived perennial plants with oval, corrugated leaves clustered in ground-level rosettes and with oval-lanceolate stem leaves. Large violet, bright purple, pink, or white bell-shaped flowers with brown spots inside, are borne in top spikes with a length of 70-80 cm, are decorative parts of this species (Świdzińska, 2000; Marcinkowski, 2002; B e r n a c i a k et al. 2007). Eight growth stages of $D$. purpurea flowers (from the smallest bud to corolla abscission) are described in the literature. Flower development lasts over a week and flowers are of the largest size just after opening (S te a d and Moor,
1977). In our own experiments, three cultivars of this species were cultivated: 'Apricot', 'Foxy', and 'Pam's Choice'. In the first year of the research, the evaluated cultivars differed in height (Table 2). In the second year, the plants were equal with regard to height (inflorescence stems were characterized by a height from 105 to $125 \mathrm{~cm}$ ). Both in 2009 and 2010, these cultivars did not differ in inflorescence length on the highest inflorescence stem and in the leaf greenness index. In both years of the experiment, the cultivar ' $\mathrm{Pa}$ m's Choice' was characterized by the shortest flowers. The other evaluated cultivars did not differ in flower length, irrespective of the year. Among all evaluated taxa of the genus Digitalis, the cultivar 'Apricot' was characterized by the highest inflorescence stems. They reached a height of over $120 \mathrm{~cm}$ and were on the average by $20 \mathrm{~cm}$ higher than in the description given by a grower (https://www.jelitto.com). The plants had large flowers with a length of 7.2-7.5 cm, with a wide bell-shaped corolla, yellow-pink at the beginning, bright pink at full bloom, fading at the end of flowering (pale pink). Some dark pink spots with a bright rim were in the lower part of the flower throat. Flowers were borne in one-sided spikes reaching a length of about $55 \mathrm{~cm}$, with 20-25 flowers. The plants were characterized by 2 inflorescence stems, on the average (Fig. 10). The cultivar 'Foxy' reached the height of 91-105 $\mathrm{cm}$. These results confirm the reports of many authors (B rickell, 1999; Świdziń ska, 2000; https://www.jelitto.com). The cultivar 'Foxy' had large, pendent flowers with a length of 6.7-7.7 cm, with a wide bell-shaped corolla of various colours: white, creamy, peach-coloured, pink to purple, usually intensely purple spotted. Flowers were borne in one-sided top spikes reaching the length of about $40 \mathrm{~cm}$ and consisting of 16-20 flowers. On the average, the plants had 2 inflorescence stems. D. purpurea 'Pam's Choice' reached a height from 83 to $108 \mathrm{~cm}$ and was lower than in the description given by a grower (https://www.jelitto. com). The plants had large flowers, a wide bell-shaped corolla with a length of $5.5-6.1 \mathrm{~cm}$, white-greenish at the beginning, white, with many red-brown spots in the lower part of the flower throat at full bloom. Flowers were borne in a one-sided spike with an average length of about $40 \mathrm{~cm}$ and consisting of 20-25 flowers. On the average, the plants had 2 inflorescence stems.

Digitalis lanata and D. lutea also belonged to the highest taxa. These plants reached a height of about $103-106 \mathrm{~cm}$, which is in agreement with the reports of S zweykowska and Szweykowski (1993) as well as Mows zowicz $(1982,1983)$. However, our own experiments did not confirm the reports of B rickell (1999) and Brenzel (2001) according to whom those two taxa reached a height of $60 \mathrm{~cm}$. D. lanata (woolly foxglove, also called Grecian 
foxglove) belongs to biennial plants or to short lived perennial plants (Mowszowicz, 1982; Mows z ow ic z, 1983). The plants were characterized by lanceolate-elongated, dark green sessile leaves. Among the evaluated taxa, they were of the most intensive green colour. The leaf greenness index amounted to 77.8 SPAD in the year 2009 and to 69.3 SPAD in the year 2010. This species was characterized by bilabial flowers of tubular shape and a corolla reaching a length of $2.7 \mathrm{~cm}$. Flowers were yellow-brown inside with dark brown streaks and a wide cream lower lip. Flowers were borne in a top, one-sided, dense, hairy spike reaching a length of $34-37 \mathrm{~cm}$. These spikes consisted of 40-50 flowers. On the average, $D$. lanata was characterized by 4 inflorescence stems, while $D$. lutea by 1 inflorescence stem. This species is often used in the pharmaceutical industry, because a valuable compound, digoxin, used in heart diseases is extracted from the leaves of this plant (Ardele n et al. 2006). Digitalis lutea is an indigenous species classified as a perennial plant (Mowszowicz, 1982; Szweykowska and Szweykowski, 1993). It was characterized by lanceolate-elongated, serrated to almost entire leaves with a similar leaf greenness index, regardless of the year (in 2009 - 57.3 SPAD, and in 2010 - 58.9 SPAD). This foxglove had bright yellow flowers. Among the evaluated taxa, its corolla was the shortest (2.1-2.2 $\mathrm{cm})$. The corolla was bilabial and slightly hairy. The plants were characterized by loose, one-sided, often frail spikes with a length of $44-45 \mathrm{~cm}$ and consisting of 50-60 flowers. The plants had 1-2 inflorescence stems.

D. $\times$ mertonensis is a seldom cultivated hybrid obtained in Great Britain in 1925 as a result of $D$. grandiflora and D. purpurea crossing (B u x t o n and Darlington, 1932; R o oney, 2007). Roon ey (2007) is of the opinion that the described species flowers in the first cultivation season and is a short lived perennial plant. In our own experiment, D. $\times$ mertonensis 'Summer King' was characterized by large, oval-lanceolate leaves with clear streaks, covered with soft hair from below, with a similar leaf greenness index regardless of the year (56.6 SPAD in 2009 and 56.7 SPAD in 2010). Stiff and erect inflorescence stems reached the height of $65 \mathrm{~cm}$, which is consistent with literature data ( $\mathrm{Brenzel}$, 2001; Grabowska and Kubala, 2010). This taxon was characterized by large, bell-shaped flowers with a length of 5.7-5.8 cm and a particularly hairy edge of the corolla. Flowers were characterized by fawn-pink colour, with darker streaks and some dark-purple spots inside the flower throat. The plants had one erect inflorescence stem reaching a length of $19-27 \mathrm{~cm}$ and consisting of more than 40 flowers.

Digitalis grandiflora is our indigenous perennial species reaching a height of 30-120 cm (S z w e y - kowska and Szweykowski, 1993; B ricke 11, 1999; Grabow s k a and K u b a la, 2010). In our own research, its plants reached a height of 57.0$62.5 \mathrm{~cm}$ and their rosettes consisted of linear, serrate leaves with the leaf greenness index of leaves between 47.3 and 54.8 SPAD. This foxglow was characterized by pendent sulphuric-yellow flowers with brown streaks inside the flower throat and a wide bell-shaped, bilabial, hairy corolla reaching a length of 3.4-3.7 cm. Flowers were borne in a top, dense, one-sided spike consisting of 20-25 flowers reaching an average length of slightly more than $25 \mathrm{~cm}$. Each plant had 4 or 5 erect inflorescence stems.

Digitalis laevigata is a perennial plant. Our own study did not confirm the opinion of B r i c kell (1999) and Brenzel (2001), according to whom it reaches a height of $100 \mathrm{~cm}$. The plants reached a height of only 76-78 cm, depending on the year of the experiment. This Grecian foxglove was characterized by obovate, green leaves with the leaf greenness index between 49.9 and 52.5 SPAD. Flowers of this species were of tubular shape. Their corolla reached a length of $3.8 \mathrm{~cm}$. Flowers were brown-yellow inside with dark, brown streaks and a wide creamy, hairy down lip. Flowers were borne in top, one-sided, loose spikes reaching a length of 42-46 cm and consisting of 30-40 flowers. On the average, this species was characterized by 4-5 inflorescence stems.

D. thapsi 'Spanish Peaks ${ }^{\circledR}$ ' is a perennial plant reaching a height of 30-45 cm (B renze 1, 2001; https://www.jelitto.com). In our own research, this plant reached a twice larger size. Plant height was on average $83-89 \mathrm{~cm}$. Leaves were softly hairy, oval, with a pointed tip and a corrugated edge. They were bright green and their leaf greenness index was the lowest in comparison with the other evaluated taxa. This foxglove was characterized by narrow bell-shaped, softly hairy flowers with a length of 5.5-5.8 cm. Flowers were of pink-violet colour. Darker, small spots on the bright background were in the lower part of the flower throat. On the average, the plants were characterized by 2 inflorescence stems with loose, one-sided spikes with a length of 35-39 cm and consisting of 20-25 flowers.

Foxgloves can be cultivated in groups of plants and can also be used in parks under trees, in combination with shrubs, in naturalistic and forest gardens ( $\mathrm{u}$ k a s i e w i c z, 1956; He 11 w i g, 1957). Unfortunately, nurseries in Poland produce a limited number of taxa of the genus Digitalis. D. purpurea and its cultivars are produced most often. Seed companies offer a modest assortment, and only seeds of $D$. purpurea (mix of colours) and the cultivar 'Gloxiniaeflora' are usually on sale. This modest offer could be greater and some unknown species and cultivars which are important should be also available on the market. 
Table 2

Morphological traits of Digitalis sp. at the generative stage

\begin{tabular}{|c|c|c|c|}
\hline \multirow{2}{*}{ Traits } & \multirow{2}{*}{ Taxon } & \multicolumn{2}{|c|}{ Year } \\
\hline & & 2009 & 2010 \\
\hline \multirow{11}{*}{ Height of plants (cm) } & D. grandiflora & 57.0 & 62.5 \\
\hline & D. laevigata & 78.4 & 75.7 \\
\hline & D. lanata & 102.7 & 98.0 \\
\hline & D. lutea & 92.4 & 105.8 \\
\hline & D. $\times$ mertonensis 'Summer King' & 55.4 & 65.0 \\
\hline & D. purpurea 'Apricot' & 121.3 & 124.2 \\
\hline & D. purpurea 'Foxy' & 90.7 & 104.7 \\
\hline & D. purpurea 'Pam's Choice' & 82.7 & 108.2 \\
\hline & D. thapsi ‘Spanish Peaks ${ }^{\circledR ’}$ & 88.8 & 82.8 \\
\hline & Mean & 85.5 & 91.9 \\
\hline & $\mathrm{LSD}_{0.05}$ & 25.69 & 26.36 \\
\hline \multirow{11}{*}{ Length of inflorescence (cm) } & D. grandiflora & 24.5 & 27.3 \\
\hline & D. laevigata & 45.9 & 41.9 \\
\hline & D. lanata & 37.3 & 34.3 \\
\hline & D. lutea & 43.7 & 45.3 \\
\hline & D. $\times$ mertonensis 'Summer King' & 18.6 & 26.8 \\
\hline & D. purpurea 'Apricot' & 55.7 & 53.1 \\
\hline & D. purpurea 'Foxy' & 38.0 & 48.4 \\
\hline & D. purpurea 'Pam's Choice' & 41.2 & 38.9 \\
\hline & D. thapsi 'Spanish Peaks ${ }^{\circledR ’}$ & 38.9 & 35.2 \\
\hline & Mean & 38.2 & 39.0 \\
\hline & $\mathrm{LSD}_{0.05}$ & 20.92 & 17.71 \\
\hline \multirow{11}{*}{ Flower length $(\mathrm{cm})$} & D. grandiflora & 3.43 & 3.72 \\
\hline & D. laevigata & 3.75 & 3.63 \\
\hline & D. lanata & 2.52 & 2.65 \\
\hline & D. lutea & 2.23 & 2.12 \\
\hline & D. $\times$ mertonensis 'Summer King' & 5.82 & 5.70 \\
\hline & D. purpurea 'Apricot' & 7.50 & 7.17 \\
\hline & D. purpurea 'Foxy' & 7.67 & 6.70 \\
\hline & D. purpurea 'Pam's Choice' & 6.13 & 5.48 \\
\hline & D. thapsi ‘Spanish Peaks ${ }^{\circledR ’}$ & 5.52 & 5.80 \\
\hline & Mean & 4.95 & 4.77 \\
\hline & $\mathrm{LSD}_{0.05}$ & 0.923 & 1.352 \\
\hline \multirow{11}{*}{ Green index (SPAD) } & D. grandiflora & 47.3 & 54.8 \\
\hline & D. laevigata & 52.5 & 49.9 \\
\hline & D. lanata & 77.8 & 69.3 \\
\hline & D. lutea & 57.3 & 58.9 \\
\hline & D. $\times$ mertonensis 'Summer King' & 56.6 & 56.7 \\
\hline & D. purpurea 'Apricot' & 44.0 & 44.1 \\
\hline & D. purpurea 'Foxy' & 48.2 & 52.6 \\
\hline & D. purpurea 'Pam's Choice' & 49.7 & 44.3 \\
\hline & D. thapsi ‘Spanish Peaks ${ }^{\circledR}$ ' & 41.3 & 45.9 \\
\hline & Mean & 52.6 & 52.9 \\
\hline & $\mathrm{LSD}_{0.05}$ & 10.94 & 8.87 \\
\hline
\end{tabular}




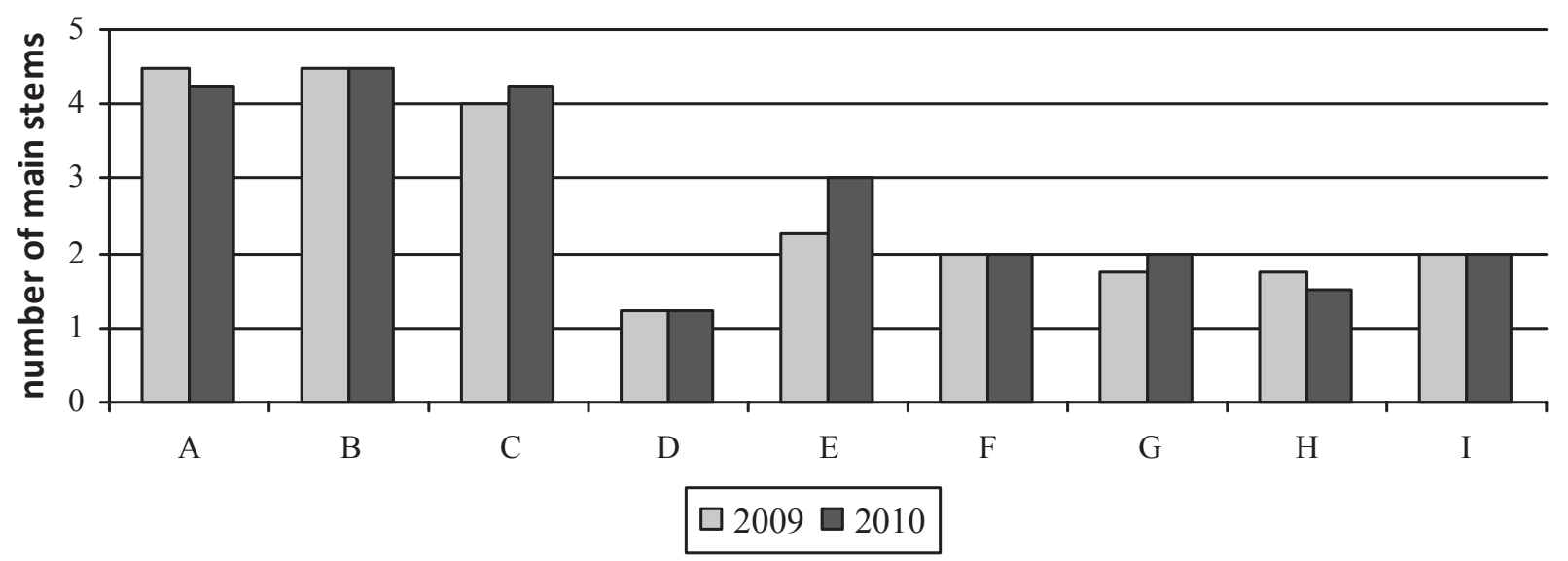

Fig. 10. Number of main stems in the taxa Digitalis sp.

Taxa: A - D. grandiflora, B - D. laevigata, C - D. lanata, D - D. lutea, E - D. x mertonensis 'Summer King', F - D. purpurea L. 'Apricot', G - D. purpurea 'Foxy', H - D. purpurea 'Pam's Choice', I - D. thapsi 'Spanish Peaks ${ }^{\circledR}$

\section{CONCLUSIONS}

1. The taxa evaluated in the experiment differed in the start date of flowering. Digitalis purpurea 'Apricot', 'Foxy', and 'Pam's Choice' bloomed earliest and were of the greatest decorative value between May and June. Digitalis laevigata and Digitalis lanata were at full bloom latest - between June and July.

2. Among the evaluated taxa, Digitalis purpurea 'Apricot' was characterized by the greatest height $-123 \mathrm{~cm}$ (on the average). Digitalis grandiflora and Digitalis $\times$ mertonensis 'Summer King' were of the smallest height. They were on the average by 48-53\% shorter than the highest cultivar.

3. Digitalis lutea was characterized by the greatest number of flowers in the inflorescence - on the average 50-60; Digitalis lanata and Digitalis laevigata had slightly less flowers. Other evaluated taxa had a similar number of flowers - about 20-25. Digitalis purpurea 'Apricot' was characterized by the longest inflorescences (54 $\mathrm{cm}$ on the average) with large flowers. Digitalis $\times$ mertonensis 'Summer King' had short inflorescences $(23 \mathrm{~cm}$ on the average), but with many densely set flowers.

4. All evaluated taxa were of high decorative value. Digitalis $\times$ mertonensis 'Summer King', Digitalis purpurea 'Apricot' and 'Pam's Choice' were found to be the most decorative because of proportional conformation, length of inflorescences, size and colour of flowers as well as abundance of flowering.

5. Digitalis grandiflora, D. laevigata, D. lanata, D. luea, D. × mertonensis 'Summer King', D. purpurea 'Apricot', 'Foxy', 'Pam's Choice' and D. thapsi 'Spanish Peaks ${ }^{\circledast}$ ' can be grown in fields in the climatic conditions of north-western Poland. The evalu- ated taxa of Digitalis should be the basic assortment of plants used in flower-beds in green areas.

\section{REFERENCES}

Ardelen M., Costea A-M. Cordea M. 2006. Breeding foxglove (Digitalis sp.) for ornamental and/or medical purposes. Buletin USAMV, 63, 1-2.

Armitage A.M., Laushman J.M. 2008. Specialty cut flowers. Timber Press, Portland USA: 250-254.

Bernaciak A., Osiecka J., Smogorzewska W. 2007. Rośliny ozdobne w architekturze krajobrazu. Cz. II. / Ornamental plants in landscaping. Part II., Hortpress Sp. z o.o., Warszawa: 140-141. (in Polish)

Brenze1 K.N. 2001. Western Garden Book. Sunset Publishing Corporation, Menlo Park, California: 317.

Brickell Ch. 1999. Wielka encyklopedia roślin ogrodowych od A do Z. Muza, Warszawa: 367-368. (in Polish)

Buxton B.H., Darlington C.D. 1932. Crosses between Digitalis purpurea and Digitalis ambiqua. The New Phytologist, XXXI, 4: 225-242.

Erhardt W., Götz E., Bödeker N., Seybold S. 2008. Zander. Handwörterbuch der Pflanzennamen. Eugen Ulmer, Stuttgart: 343 (in German)

Gregorczyk A., Raczyńska A. 1998. Badania korelacji między metodą Arnona, a pomiarami zawartości chlorofilu za pomocą chlorofilometru. / Investigations of correlation between Arnon's method and chlorophyll content measurements by using a chlorophyll meter. Zesz. Nauk. AR Szczecin, 181: 119-123. (in Polish)

Grabowska B., Kubala T. 2010. Byliny w twoim ogrodzie. Wydawnictwo Zysk i S-ka, Poznań: 151-152. (in Polish)

Hel1w ig Z. 1975. Byliny w parku i ogrodzie. Państwowe Wydawnictwo Rolnicze i Leśne, Warszawa: 96. (in Polish)

https://www.jelitto.com

http://www.hrt.msu.edu/perennialresearch/Perennial/Summary/ Digitalis_Foxy.pdf 
Marcinkowski J. 2002. Byliny ogrodowe. Państwowe Wydawnictwo Rolnicze i Leśne, Warszawa: 199-200. (in Polish)

Łukasiewicz A. 1956. Krajowe byliny ozdobne. Państwowe Wydawnictwo Naukowe, Poznań: 75-76. (in Polish)

Macoboy S. 2003. Kwiaty - ilustrowana encyklopedia. / What Flower is that? Wyd. Elipsa, Warszawa: 139-140. (in Polish)

Mowszowicz J. 1982. Przewodnik do oznaczania krajowych roślin trujących i szkodliwych. Państwowe Wydawnictwo Rolnicze i Leśne, Warszawa: 344-345. (in Polish)

Mows zow ic z J. 1983. Przewodnik roślin zielarskich. Państwowe Wydawnictwo Rolnicze i Leśne, Warszawa: 344-345. (in Polish)

$\mathrm{Nau}$ J. 1993. Ball culture guide. The encyclopedia of seed germination. Ball Publishing, Batavia, Illinois: 143.

Nowak J., Rudnicki R.M. 1990. Postharvest handling and storage of cut flowers. Florist greens and potted plants. Timber Press, Portland, Oregon: 36.

Olgelbrand S. 1865. Encyklopedyja powszechna. Tom XIX. Wyd. Olgelbranda, Warszawa: 176-177.

Rooney D. 2007. Odd-bots among the foxgloves. New Zealand Garden Journal, 10 (2): 17-19.

Stead A.D., Moore K.G. 1977. Flower development and senescence in Digitalis purpurea L., cv. Foxy. Ann. Bot. 41: 283-292.

Świdzińska M. 2000. Rośliny dwuletnie. [In]: Uprawa roślin ozdobnych. H. Chmiel, (ed.), Państwowe Wydawnictwo Rolnicze i Leśne, Warszawa: 317-318. (in Polish)

Szweykowska A., Szweykowski J. 1993. Słownik botaniczny. Wiedza Powszechna, Warszawa: 399-400. (in Polish)

\section{Ocena wartości dekoracyjnej kilku taksonów z rodzaju Digitalis}

\section{Streszczenie}

W latach 2008-2010 przeprowadzono ocenę wartości dekoracyjnej $D$. grandiflora Mill., D. laevigata Waldst. et Kit., D. lanata Ehrh., D. lutea L., $D . \times$ mertonensis 'Summer King', D. purpurea L. 'Apricot', 'Foxy', 'Pam's Choice' i D. thapsi L. 'Spanish Peaks ${ }^{\circledR}$. Oceniano rośliny w stadium wegetatywnym i generatywnym.

Rozsada naparstnic charakteryzowała się wysoką jakością wynikającą z proporcjonalnej budowy rozet liściowych, zdrowego wyglądu, bez oznak chorób i szkodników. Najwcześniej zakwitały odmiany Digitalis purpurea oraz Digitalis $\times$ mertonensis 'Summer King', a najpóźniej pełnię walorów dekoracyjnych uzyskała $D$. laevigata i $D$. lanata. Do najobficiej kwitnących należała $D$. lutea, D. lanata i D. laevigata. Najdłuższe kwiatostany z dużymi kwiatami miała naparstnica purpurowa 'Apricot'. Stosunkowo krótkie kwiatostany, ale z bardzo gęsto osadzonymi kwiatami, wytwarzała Digitalis × mertonensis 'Summer King'. Badane taksony odznaczały się wysokimi walorami zdobniczymi. Mogą być wprowadzane do uprawy gruntowej w warunkach klimatycznych Polski północno-zachodniej. Za najbardziej dekoracyjne uznano: Digitalis $\times$ mertonensis 'Summer King', Digitalis purpurea 'Apricot' i 'Pam's Choice'. 
